\title{
Mannan-oligosaccharide and organic acids for weaned piglets
}

\section{Mananoligossacarídeo e ácidos orgânicos para leitões desmamados}

\author{
Marcia de Souza Vieira ${ }^{1 *}$; Julio Cezar Dadalt²; Andréa Machado Leal Ribeiro ${ }^{3}$; \\ Thiago William de Almeida ${ }^{4}$
}

\begin{abstract}
This study aimed to evaluate the effect of acetic, propionic, and formic (50\%) organic acids and mannanoligosaccharide $(50 \%)$ on growth performance, digestibility, and faecal score in challenged weaned piglets. Twenty male piglets (5.57 $\pm 0.32 \mathrm{~kg}$ of BW; $21-24$ days of age) were housed individually in metabolic cages for 28 days in an acclimatised room. The treatments were composed of the inclusion $(0.1 \% ; n=10)$ or not $(n=10)$ of additive in the diet. The experimental design was completely randomised with two treatments, 10 replicates, and one piglet per replicate. The nutritional matrix was supplemented with $10 \%$ of barley and 35.9 to $34.0 \%$ of soybean meal in the pre-starter diet (3-14 days post-weaning) and the starter diet (15-28 days post-weaning), respectively, to cause an intestinal challenge. Diets did not include any antimicrobial or growth promoters. Weekly, the animal and the leftover diet were weighed to evaluate growth performance. Digestibility was evaluated through total faeces and urine collection. Piglets fed diets with additive had $8.7 \%$ greater weight gain $(P<0.05)$ compared to those piglets in the control treatment in the starter phase. For other growth performance responses there was no treatment effect. Similarly, the inclusion of additive in the piglet diets did not affect the faecal score or the energy and nutrient digestibility. In the starter phase and throughout the experimental period, piglets fed diets with additive had $18.37 \%$ and $15.07 \%$ greater nitrogen $(\mathrm{N})$ intake and $19.53 \%$ and $16.05 \%$ greater $\mathrm{N}$ retention, respectively, compared to piglets in the control treatment $(P<0.05)$. In conclusion, the addition of additive composed by organic acids and mannan-oligosaccharide does not improve energy and nutrient digestibility but increases the $\mathrm{N}$ retention and weight gain in weaned piglets in the starting phase.
\end{abstract}

Key words: Nutritional additive. Intestinal challenge. Pigs. Prebiotic.

\section{Resumo}

O presente estudo foi realizado com o objetivo de avaliar os efeitos da suplementação de ácidos orgânicos, acético, propiônico e fórmico (50\%) e mananoligossacarídeo (50\%), sobre o desempenho, digestibilidade e escore fecal de leitões desafiados. Assim, vinte leitões (21 - 24 d idade), machos castrados, com peso inicial de 5,57 $\pm 0,32 \mathrm{~kg}$ foram alojados em gaiolas de metabolismo por 28 dias, em sala climatizada. Os tratamentos foram compostos pela inclusão $(0,1 \% ; n=10)$ ou não $(n=10)$ do aditivo à dieta. $\mathrm{O}$ delineamento experimental foi inteiramente casualizado com dois tratamentos,

1 Pós-Doutoranda, Programa de Pós Graduação em Zootecnia, Universidade Federal do Paraná, UFPR, Departamento de Zootecnia, Curitiba, PR, Brasil. E-mail: msvzootec@yahoo.com.br

2 Prof., Universidade Federal de Santa Catarina, UFSC, Campus Curitibanos, Curitibanos, SC, Brasil. E-mail: julio@zootecnista. com.br

3 Profa, Universidade Federal do Rio Grande do Sul, UFRGS, Departamento de Zootecnia, Porto Alegre, RS, Brasil. E-mail: aribeiro@ufrgs.br

4 Discente, Curso de Mestrado do Programa de Pós-Graduação em Zootecnia e Engenharia de Alimentos, Universidade de São Paulo, USP, Faculdade de Zootecnia e Engenharia de Alimentos, FZEA, Pirassununga, SP, Brasil. E-mail: almeidatw@usp.br

* Author for correspondence

Received: Mar. 03, 2017 Approved: May 24, 2017 
10 repetições e um animal por repetição. Utilizou-se $10 \%$ de cevada e 35,9 e $34,0 \%$ de farelo de soja na matriz nutricional da dieta pré-inicial (de três a 14 dias pós desmame) e inicial (de 15 a 28 dias pós desmame), respectivamente, com o objetivo de causar um desafio intestinal para os leitões. Não foi usado nenhum tipo de antimicrobiano ou promotor de crescimento. Diariamente o escore fecal foi registrado e semanalmente foi feita pesagem das sobras de ração e dos animais para avaliação do desempenho. A digestibilidade foi avaliada por meio de coleta total de fezes e urina. Leitões suplementados com o aditivo apresentaram ganho de peso $8,7 \%$ maior $(\mathrm{P}<0,05)$ que aqueles no tratamento controle, na fase inicial. Para as outras respostas de desempenho não houve diferença significativa entre os tratamentos. Da mesma forma, a adição de aditivo à dieta não afetou o escore fecal e a digestibilidade dos nutrientes e da energia bruta. Na fase inicial e no período total, leitões que receberam o aditivo na dieta apresentaram 18,37 e 15,07\% maior nitrogênio consumido e 19,53 e 16,05\% maior nitrogênio retido, respectivamente, quando comparado aos leitões do tratamento controle $(\mathrm{P}<0,05)$. A adição do aditivo, contendo ácidos orgânicos e mananoligossacarídeo, não contribui para a melhora na digestibilidade dos nutrientes e da energia, porém aumenta a retenção de nitrogênio e o ganho de peso dos leitões.

Palavras-chave: Aditivo nutricional. Desafio intestinal. Prebiótico. Suínos.

\section{Introduction}

The higher susceptibility of weaned piglets to anorexia, with long periods among large feed intake portions, makes the nursery phase critical in the pig production system (BROOKS et al., 2001; SUIRYANRAYNA; RAMANA, 2015). The low growth performance observed in this phase is directly related to the occurrence of gastrointestinal disorders, mainly diarrhoea caused by pathogenic bacteria (ADEWOLE et al., 2016). Thus, dietary additives such as organic acids (BOAS et al., 2016; DEVI et al., 2016; ZHANG et al., 2016) and mannan-oligosaccharides (FESSELE; LINDHORST, 2013; GIANNENAS et al., 2016; WENNER et al., 2013) have been used to increase growth performance, decrease diarrhoea mortality, and modify the intestinal environment of pigs after weaning.

Organic acids act mainly in gastric $\mathrm{pH}$ reduction, increasing stomach acidification and improving protein digestion by pepsin. Furthermore, $\mathrm{pH}$ reduction prevents the colonisation of pathogenic bacteria such as E. coli and Salmonella (BUSSER et al., 2011; CALVEYRA et al., 2012; WALSH et al., 2012), promotes proliferation of intestinal cells, increases the villous size and absorptive capacity (DIAO et al., 2015, 2016), and improves immune capacity (KUANG et al., 2015) in weaned piglets.
In relation to mannan-oligosaccharide effects, previous studies have reported three distinct responses. The first concerns the beneficial modulation of the native microbiota present in the host. The second is the possible enhancing action on gut physiology, such as papillae increase. The third is a direct consequence of both the first and second through the influence of these compounds on animal performance (HALAS; NOCHTA, 2012; SILVA; NÖRNBERG, 2003).

Therefore, diet supplementation with a product based on mannan-oligosaccharide and organic acids (acetic, formic, and propionic) could improve weaned piglets' growth performance. Therefore, this study aimed to evaluate the effects of dietary supplementation with the above-mentioned additives on performance, digestibility, and faecal score in challenged piglets.

\section{Material and Methods}

The trial was carried out at the Zootechnical Laboratory at the Federal University of Rio Grande do Sul (UFRGS), Porto Alegre, Brazil. All procedures used in this experiment were approved by the Animal Experimentation Ethics Committee (protocol no. 19602).

Twenty castrated male piglets (21-24 days old) 
with $5.57 \pm 0.32 \mathrm{~kg}$ of BW were individually housed, after weaning, in metabolism cages for 28 days. The cages $\left(0.48 \mathrm{~m}^{2}\right)$ were equipped with a feeder and drinker, and the pigs were maintained inside an air-conditioned room $\left(28^{\circ} \mathrm{C}\right)$. Dietary treatments were supplemented with $0.1 \%$ or $0,0 \%$ of additive containing mannan-oligosaccharide $(50 \%)$ and a mixture of acetic, propionic, and formic organic acids (50\%). The experiment was conducted in two growing phases: pre-starter, between 3 and 14 days after weaning, and starter, between 15 and 28 days post-weaning. The data were also evaluated in the total period (3-28 days). Feed and water were provided ad libitum throughout the experimental period.

Two diets were formulated to be isocaloric and isoproteic (one diet for the pre-starter phase and another for the starter phase - Table 1) and either meet or exceed all other nutrient requirements
(ROSTAGNO et al., 2005). The diets were supplemented with $10.0 \%$ of barley to induce a challenge in the gastrointestinal tract of the piglets. Barley contains a large amount of nonstarch polysaccharides compared to corn and thus has lower digestibility. Also, a higher amount of soybean meal was used than what is recommended for the age of the piglets $(35.9 \%$ and $34.0 \%$ for the pre-starter and starter phases, respectively). No lactose was included in the diets, and the levels of this nutrient were only met by the addition of whey powder in the percentages of $14.0 \%$ and $8.3 \%$ in the pre-starter and starter diets, respectively. No other growth promoter commonly used in the pre-starter and starter phases, such as zinc oxide, copper, or antimicrobial, was used in the diet. The animals and the leftovers were weighed weekly, and the average daily feed intake (ADFI), average daily gain (ADG), and gain:feed ratio (G:F) were calculated.

Table 1. Composition of the experimental diets (based on natural matter), provided in the period from 1 to 14 days (Pre-starter) and from 15 to 28 days (Starter) post-weaning.

\begin{tabular}{lcc}
\hline Item & Pre-starter $^{1}$ & Starter $^{1}$ \\
\hline Ingredient $\left(\mathrm{g} \mathrm{kg}^{-1)}\right.$ & & \\
Corn & 239.20 & 342.00 \\
Soybean meal & 359.40 & 340.00 \\
Whey powder & 200.00 & 114.30 \\
Barley & 100.00 & 100.00 \\
Coconut fat & 40.00 & 40.00 \\
Sugar & 30.00 & 30.00 \\
Monocalcium phosphate & 12.20 & 14.40 \\
Limestone & 6.40 & 6.50 \\
Salt & 3.30 & 3.70 \\
L-Lysine HCL (99\%) & 3.00 & 3.60 \\
DL-Methionine (98.5\%) & 2.90 & 1.90 \\
L-Threonine (99\%) & 1.60 & 1.70 \\
Premix Vitamin and Mineral & 1.30 \\
Choline & 1.30 & 1.30 \\
Nutritional composition $\left(\mathrm{g} \mathrm{kg}^{1}\right)$ & 0.70 & 0.60 \\
Metabolisable energy (Mcal kg-1) & & \\
Crude protein & 3,530 & 3,510 \\
& 200.00 & 200.00
\end{tabular}

Continue... 
Continuation...

$\begin{array}{lcc}\text { Ether extract } & 5.85 & 6.13 \\ \text { Calcium } & 7.00 & 7.50 \\ \text { Available phosphorus } & 5.00 & 4.60 \\ \text { Digestible lysine } & 13.60 & 13.20 \\ \text { Neutral detergent fiber } & 95.20 & 104.80 \\ \text { Digestible methionine }+ \text { cystine } & 8.80 & 7.70 \\ \text { Digestible tryptophan } & 2.50 & 2.30 \\ \text { Digestible threonine } & 9.10 & 8.70\end{array}$

${ }^{1}$ Levels per kg of product: Vitamin A, 14400 IU; Vitamin D3, 2700 IU; Vitamin E, 32.40 mg; Vitamin K, 3.60 mg; Vitamin B1, 2.88 mg; Vitamin B2, 9.18 mg; Vitamin B6, 2.79 mg; Vitamin B12, 34.20 mg; Pantothenic acid, 23.40 mg; Niacin, 46.80 mg; Folic acid, $0.81 \mathrm{mg}$ and biotin, $162 \mathrm{mcg}$. Selenium, $0.48 \mathrm{mg}$; Iodine, $0.56 \mathrm{mg}$; Iron, $64.0 \mathrm{mg}$; Copper, $12.80 \mathrm{mg}$; Zinc, $128.0 \mathrm{mg}$ and Manganese, $48.0 \mathrm{mg}$.

The pigs were fed experimental diets for a nineday adaptation period, followed by a five-day period of total collection of faeces and urine. Ferric oxide $\left(\mathrm{Fe}_{2} \mathrm{O}_{3}\right)$ was added to the diets at $0.30 \%$ to determine the collection timeframe by the appearance of marked faeces (ADEOLA, 2001). Faecal and urine collections were performed once a day. The faeces were weighed and stored in identified plastic bags. Urine was collected in plastic containers with 25 $\mathrm{mL}$ of $6 \mathrm{~N} \mathrm{H}_{2} \mathrm{SO}_{4}$ to minimise $\mathrm{NH}_{3}$ volatilisation. The volume was weighed daily, and a $10.0 \%$ aliquot was removed and refrigerated at $-15^{\circ} \mathrm{C}$.

The faeces were evaluated daily (4-28 days postweaning) for consistency through subjective faecal score evaluation according to the following scale: 1 $=$ hard and dry stools; 2 = normal stool consistency (firm); 3 = soft stools but non-diarrhoeic; 4 = watery stools with diarrhoea characteristics. A total of 500 faecal score observations were made. The values found in the first three days of the experimental period were excluded due to the absence of faeces in most experimental units.

The diet samples were collected, homogenised, sub-sampled (about $500 \mathrm{~g}$ ), and stored at $-20^{\circ} \mathrm{C}$ for posterior analyses. Similarly, at the end of the experimental period, the faeces and urine samples were thawed, homogenised, sub-sampled (500 $\mathrm{g}$ and $100 \mathrm{~mL}$ per replicate, respectively), and analysed.
The analyses were performed according to AOAC (1995) procedures.

Diets and faeces samples were ground to pass through a $1 \mathrm{~mm}$ sieve (Model EDB-5, De Leo Laboratory Equipments, Porto Alegre, Brazil). The dry matter (DM) in the faeces was determined after the samples were dried in a forced air oven at $60^{\circ} \mathrm{C}$ for 72 hours. Subsequently, drying was done at $105^{\circ} \mathrm{C}$ for 12 hours (AOAC, 1995). The nitrogen $(\mathrm{N})$ content in the diets (in natural matter) and faeces (pre-dried in a greenhouse at $105^{\circ} \mathrm{C}$ ) was determined by the Micro-Kjeldhal method (AOAC, 1995, adapted by PRATES, 2007). Crude protein (CP) was calculated as $\mathrm{N} \times 6.25$. The gross energy (GE) of the diets, faeces, and freeze-dried urine samples was determined using an adiabatic oxygen bomb calorimeter (C2000 - IKA Werke GmbH\&Co. KG, Staufen, Germany) with benzoic acid (6318 $\left.\mathrm{kcal} \mathrm{kg}{ }^{-1}\right)$ used for calibration $\left(6317 \pm 2 \mathrm{kcal} \mathrm{kg}^{-1}\right.$ in the assay). Crude fat was determined after ether extraction (AOAC, 1995) in an extractor apparatus. Urine samples were dried in a forced-ventilation oven at $60{ }^{\circ} \mathrm{C}$ for $72 \mathrm{~h}$ (AOAC, 1995) and analyzed for GE content as described above. Urinary $\mathrm{N}$ was determined in the liquid sample (AOAC, 1995) as described above. All analyses were performed in duplicate, and the standard deviation between replicates was less than $5 \%$ for all methods and less than $1 \%$ for energy. 
The experimental design was completely randomised with two treatments, 10 replicates, and one animal per replicate. Statistical analysis was performed by ANOVA using the Generalised Linear Model (SAS ${ }^{\circledR}$, Inst. Inc., Cary, NC, USA), and the means were compared by the F test. For the faecal score analysis, the non-parametric test of KruskallWallis (5\%) was used. The animal was considered the experimental unit and the results were considered significant if $P \leq 0.05$ and trending if $P<0.10$.

\section{Results}

No pigs were removed from the trial during the study. In the pre-starter and total phases, no additive effect was found on pig performance; however, in the starter phase, the piglets fed with supplemented diets had $8.7 \%$ higher ADG than the control treatment $(\mathrm{P}<0.05)$. There was no additive effect on ADFI and G:F (Table 2).
The additive supplementation in the diet did not influence the digestibility responses in any of the evaluated phases (Table 3). In the starter phase, piglets fed with a supplemented diet had higher $\mathrm{N}$ intake and absorption $(P<0.05)$, which were $18.37 \%$ and $19.53 \%$ higher than in the control treatment (Table 4), respectively. Similarly, in the total phase, piglets fed with a supplemented diet had higher $\mathrm{N}$ intake and absorption $(P<0.05)$, which were $15.07 \%$ and $16.05 \%$ higher than in the control treatment (Table 4), respectively. There was a trend $(P<0.10)$ of higher $\mathrm{N}$ retention in the initial $(25.38 \%)$ and total $(19.74 \%)$ phases for piglets fed supplemented diets compared to control diets. For other responses of $\mathrm{N}$ balance, no additive effect was found. The use of additives in the diet did not modify the faecal score; $89 \%$ of faeces had normal to soft appearance, whereas those with a diarrhoeal appearance appeared in only $7.8 \%$ (Table 5 ).

Table 2. Growth performance of piglets fed the experimental diets ${ }^{1}$.

\begin{tabular}{|c|c|c|c|c|}
\hline Item & Control & Additive $^{2}$ & SEM $^{3}$ & $P$-value ${ }^{4}$ \\
\hline \multicolumn{5}{|c|}{ Body weight $(\mathrm{kg})$} \\
\hline Starter & 5.81 & 5.99 & 0.13 & 0.33 \\
\hline Final & 17.50 & 18.69 & 0.54 & 0.14 \\
\hline \multicolumn{5}{|c|}{ Pre-starter (3 - $14 d)$} \\
\hline $\operatorname{ADFI}\left(\mathrm{g} \mathrm{d}^{-1}\right)$ & 349 & 374 & 24 & 0.45 \\
\hline $\mathrm{ADG}\left(\mathrm{g} \mathrm{d}^{-1}\right)$ & 280 & 297 & 19 & 0.54 \\
\hline $\mathrm{G}: \mathrm{F}\left(\mathrm{g} \mathrm{g}^{-1}\right)$ & 1.24 & 1.29 & 0.04 & 0.57 \\
\hline \multicolumn{5}{|c|}{ Starter $(15-28 d)$} \\
\hline $\operatorname{ADFI}\left(\mathrm{g} \mathrm{d}^{-1}\right)$ & 820 & 885 & 42 & 0.29 \\
\hline $\mathrm{ADG}\left(\mathrm{g} \mathrm{d}^{-1}\right)$ & $663 b$ & $726 a$ & 21 & 0.05 \\
\hline $\mathrm{G}: \mathrm{F}\left(\mathrm{g} \mathrm{g}^{-1}\right)$ & 1.23 & 1.22 & 0.05 & 0.86 \\
\hline \multicolumn{5}{|c|}{ Total $(3-28 d)$} \\
\hline $\operatorname{ADFI}\left(\mathrm{g} \mathrm{d}^{-1}\right)$ & 580 & 625 & 28 & 0.27 \\
\hline ADG $\left(\mathrm{g} \mathrm{d}^{-1}\right)$ & 468 & 508 & 18 & 0.13 \\
\hline $\mathrm{G}: \mathrm{F}\left(\mathrm{g} \mathrm{g}^{-1}\right)$ & 1.24 & 1.23 & 0.04 & 0.95 \\
\hline
\end{tabular}

${ }^{1}$ ADFI: Average daily feed intake; ADG: Average daily gain; G:F: Gain:Feed.

${ }^{2}$ Additive compound by $50 \%$ of mannan-oligosaccharide and $50 \%$ of organic acids (acetic, propionic and formic).

${ }^{3} \mathrm{SEM}=$ Standard error of mean.

${ }^{4}$ Means were compared by the $\mathrm{F}$ test $(P \leq 0.05)$. 
Table 3. Apparent total tract digestibility of nutrients and energy of piglets fed the experimental diets ${ }^{1}$.

\begin{tabular}{|c|c|c|c|c|}
\hline Item $^{2}$ & Control & Additive $^{3}$ & SEM $^{4}$ & $P$-value ${ }^{5}$ \\
\hline \multicolumn{5}{|l|}{ Pre-starter (3 - $14 d)$} \\
\hline $\operatorname{DCDM}(\%)$ & 87.50 & 87.70 & 0.76 & 0.85 \\
\hline $\operatorname{DCCP}(\%)$ & 85.44 & 85.90 & 1.03 & 0.75 \\
\hline DCGE (\%) & 85.64 & 85.65 & 0.86 & 0.99 \\
\hline DCME (\%) & 83.50 & 83.39 & 0.81 & 0.92 \\
\hline GE $($ Mcal kg-1) & 4.89 & 4.86 & - & - \\
\hline DE $($ Mcal kg-1) & 4.19 & 4.17 & 0.04 & 0.69 \\
\hline ME (Mcal kg-1) & 4.08 & 4.05 & 0.03 & 0.58 \\
\hline ME: DE & 0.975 & 0.974 & 0.001 & 0.67 \\
\hline \multicolumn{5}{|l|}{ Starter (15 - $28 d)$} \\
\hline $\operatorname{DCDM}(\%)$ & 86.51 & 88.87 & 1.11 & 0.15 \\
\hline $\operatorname{DCCP}(\%)$ & 82.56 & 84.90 & 1.35 & 0.23 \\
\hline DCGE $(\%)$ & 84.43 & 86.63 & 1.24 & 0.23 \\
\hline DCME $(\%)$ & 81.92 & 84.43 & 1.39 & 0.22 \\
\hline GE $($ Mcal kg-1) & 4.80 & 4.80 & - & - \\
\hline DE $($ Mcal kg-1) & 4.05 & 4.15 & 0.06 & 0.23 \\
\hline ME (Mcal kg-1) & 3.93 & 4.05 & 0.06 & 0.23 \\
\hline ME: DE & 0.968 & 0.974 & 0.01 & 0.17 \\
\hline \multicolumn{5}{|l|}{ Total $(3-28 d)$} \\
\hline $\operatorname{DCDM}(\%)$ & 87.00 & 88.29 & 0.73 & 0.23 \\
\hline $\operatorname{DCCP}(\%)$ & 83.00 & 85.40 & 0.95 & 0.31 \\
\hline DCGE (\%) & 85.03 & 86.14 & 0.82 & 0.36 \\
\hline MCGE (\%) & 82.71 & 83.91 & 0.85 & 0.33 \\
\hline GE $\left(\right.$ Mcal kg $\left.{ }^{-1}\right)$ & 4.84 & 4.83 & - & - \\
\hline DE $\left(\right.$ Mcal kg $\left.{ }^{-1}\right)$ & 4.12 & 4.16 & 0.04 & 0.47 \\
\hline ME $($ Mcal kg-1) & 4.01 & 4.05 & 0.04 & 0.45 \\
\hline ME: DE & 0.972 & 0.974 & 0.01 & 0.71 \\
\hline
\end{tabular}

${ }^{1} \mathrm{DCDM}=$ digestibility coefficient of dry matter; DCCP = digestibility coefficient of crude protein; DCGE = digestibility coefficient of gross energy; $\mathrm{MCGE}=$ metabolizable coefficient of gross energy; $\mathrm{GE}=$ gross energy; $\mathrm{DE}=$ digestible energy; $\mathrm{ME}=$ metabolizable energy.

${ }^{2}$ The digestibility coefficients and DE and ME were calculated based on dry matter.

${ }^{3}$ Additives were compound by $50 \%$ of mannan-oligosaccharide and $50 \%$ of organic acids (acetic, propionic and formic).

${ }^{4} \mathrm{SEM}=$ Standard error of mean.

${ }^{5}$ Means were compared by the $\mathrm{F}$ test $(P \leq 0.05)$. 
Table 4. Nitrogen balance of piglets fed the experimental diets ${ }^{1}$.

\begin{tabular}{|c|c|c|c|c|}
\hline Item $^{2}$ & Control & Additive $^{3}$ & $\mathrm{SEM}^{4}$ & $P$-value ${ }^{5}$ \\
\hline \multicolumn{5}{|l|}{ Pre-starter (3 - 14 d) } \\
\hline $\mathrm{N}$ intake $\left(\mathrm{g} \mathrm{d}^{-1}\right)$ & 16.04 & 17.47 & 1.23 & 0.42 \\
\hline $\mathrm{N}$ feces $\left(\mathrm{g} \mathrm{d}^{-1}\right)$ & 2.40 & 2.50 & 0.32 & 0.82 \\
\hline $\mathrm{N}$ urine $\left(\mathrm{g} \mathrm{d}^{-1}\right)$ & 2.65 & 2.89 & 0.23 & 0.48 \\
\hline $\mathrm{N}$ absorbed $\left(\mathrm{g} \mathrm{d}^{-1}\right)$ & 13.64 & 14.97 & 0.96 & 0.34 \\
\hline $\mathrm{N}$ retained $\left(\mathrm{g} \mathrm{d}^{-1}\right)$ & 10.99 & 12.08 & 0,99 & 0.45 \\
\hline $\mathrm{N}$ retained ${ }^{-1}$ absorbed & 0.79 & 0.80 & 0.02 & 0.87 \\
\hline $\mathrm{N}$ digestibility (\%) & 67.85 & 68.74 & 1.54 & 0.69 \\
\hline $\operatorname{BVCP}(\%)$ & 80.57 & 80.69 & 2.12 & 0.84 \\
\hline \multicolumn{5}{|l|}{ Starter $(15-28 d)$} \\
\hline $\mathrm{N}$ intake $\left(\mathrm{g} \mathrm{d}^{-1}\right)$ & $29.60 \mathrm{~b}$ & $36.26 \mathrm{a}$ & 2.04 & 0.03 \\
\hline $\mathrm{N}$ feces $\left(\mathrm{g} \mathrm{d}^{-1}\right)$ & 4.83 & 5.49 & 0.32 & 0.16 \\
\hline $\mathrm{N}$ urine $\left(\mathrm{g} \mathrm{d}^{-1}\right)$ & 7.53 & 7.67 & 1.21 & 0.94 \\
\hline $\mathrm{N}$ absorbed $\left(\mathrm{g} \mathrm{d}^{-1}\right)$ & $24.76 \mathrm{~b}$ & $30.77 \mathrm{a}$ & 1.94 & 0.04 \\
\hline $\mathrm{N}$ retained $\left(\mathrm{g} \mathrm{d}^{-1}\right)$ & 17.23 & 23.09 & 2.14 & 0.07 \\
\hline $\mathrm{N}$ retained ${ }^{-1}$ absorbed & 0.66 & 0.75 & 0.06 & 0.30 \\
\hline $\mathrm{N}$ digestibility (\%) & 60.91 & 63.58 & 3.54 & 0.59 \\
\hline BVCP $(\%)$ & 69.59 & 75.04 & 2.50 & 0.58 \\
\hline \multicolumn{5}{|l|}{ Total $(3-28 d)$} \\
\hline $\mathrm{N}$ intake $\left(\mathrm{g} \mathrm{d}^{-1}\right)$ & $22.82 \mathrm{~b}$ & $26.87 \mathrm{a}$ & 1.35 & 0.05 \\
\hline $\mathrm{N}$ feces $\left(\mathrm{g} \mathrm{d}^{-1}\right)$ & 3.62 & 4.00 & 0.28 & 0.35 \\
\hline $\mathrm{N}$ urine $\left(\mathrm{g} \mathrm{d}^{-1}\right)$ & 5.09 & 5.28 & 0.66 & 0.84 \\
\hline $\mathrm{N}$ absorbed $\left(\mathrm{g} \mathrm{d}^{-1}\right)$ & $19.20 \mathrm{~b}$ & $22.87 \mathrm{a}$ & 1.18 & 0.04 \\
\hline $\mathrm{N}$ retained $\left(\mathrm{g} \mathrm{d}^{-1}\right)$ & 14.11 & 17.58 & 1.24 & 0.06 \\
\hline $\mathrm{N}$ retained ${ }^{-1}$ absorbed & 0.73 & 0.78 & 0.03 & 0.32 \\
\hline $\mathrm{N}$ digestibility (\%) & 61.34 & 66.16 & 2.88 & 0.25 \\
\hline BVCP $(\%)$ & 73.49 & 76.87 & 2.30 & 0.95 \\
\hline
\end{tabular}

${ }^{1} \mathrm{BVCP}=$ biological value of crude protein.

${ }^{2}$ Nitrogen balance was calculated based on dry matter.

${ }^{3}$ Compound by $50 \%$ and $50 \%$ mannanoligosaccharide organic acids (acetic, propionic and formic).

${ }^{4} \mathrm{SEM}=$ standard error of mean.

${ }^{5}$ Means were compared by the $\mathrm{F}$ test $(P \leq 0.05)$. 
Table 5. Faecal score observation in piglets fed the experimental diets from 4 to 28 days of age ${ }^{1}$.

\begin{tabular}{|c|c|c|c|c|c|c|}
\hline Score & Control (n) & Additive (n) ${ }^{2}$ & Total (n) & Control (\%) & Additive $(\%)^{2}$ & Total (\%) \\
\hline 1- Hard & 10 & 6 & 16 & 4.0 & 2.4 & 3.2 \\
\hline 2- Firm & 105 & 116 & 221 & 42.0 & 46.4 & 44.2 \\
\hline 3- Soft & 113 & 111 & 224 & 45.2 & 44.4 & 44.8 \\
\hline 4- Watery & 22 & 17 & 39 & 8.0 & 6.8 & 7.8 \\
\hline Total & 250 & 250 & 500 & 100 & 100 & 100 \\
\hline
\end{tabular}

${ }^{1}$ There was no significant difference between treatments in accordance with the Kruskal-Wallis test $(P \leq 0.05)$.

${ }^{2}$ Compound by $50 \%$ and $50 \%$ mannanoligosaccharide organic acids (acetic, propionic and formic).

\section{Discussion}

In the present study, we hypothesised that weaned piglets' diets supplemented with an additive composed of $50 \%$ mannan-oligosaccharide and $50 \%$ organic acids could improve the growth performance by improving the absorption/digestion capacity of nutrients and reducing the diarrhoea incidence. There was no additive effect on ADFI in any period evaluated, and it can be inferred that the additive did not influence diet palatability. Some researchers have reported that supplementation with organic acids in isolated or mixed form could negatively influence consumption by low palatability (WALSH et al., 2007), mainly mixtures with propionic and formic acids, which are considered as having an odor and unpleasant taste (SUIRYANRAYNA; RAMANA, 2015). Few studies have been able to show the effects of organic acid or manan-oligosaccharide on feed intake. Walsh et al. (2007) observed an increase in ADFI in piglets receiving diets with a mixture $(0.4 \%)$ of lactic, propionic, citric, and benzoic acids. Zhao et al. (2012) reported higher feed intake in pigs fed mannan-oligosaccharide diets $(0.5 \%)$. In contrast, Boas et al. (2016), working with a mixture $(0.5 \%)$ of lactic, formic, and citric acids; Walsh et al. (2012), with (2.58 $\left.\mathrm{mL} \mathrm{L}^{1}\right)$ propionic, acetic, and benzoic acid; and Santos et al. (2010) and Marinho et al. (2007), with mannan-oligosaccharide (inclusion levels from 0.2 to $0.75 \%$ ), did not observe an effect of additives on feed intake. In summary, the effects of organic acids and prebiotics such as mannanoligosaccharide on growth performance are credited to the improvement in nutrient utilisation of the diet and not to an increase in feed intake.

In addition, the supplementation effect may significantly alter depending on the addition of one additive or the combination of several, as in the present work. Poeikhampha and Bunchasak (2011), Corassa et al. (2012), and Giannenas et al. (2016), working with different acid and mannanoligosaccharides mixtures, were able to observe the synergistic effect of these additives, mainly on ADG and G:F. The results of the present study did not show synergy of these additives on G:F. However, there was improvement on ADG in the starter phase. This result was not repeated when analysing the whole evaluation period, showing that this gain was diluted in the total period.

There was no effect of the additives on nutrient and energy digestibility. However, animals that received additive in the diet had higher intake and absorption of $\mathrm{N}$ in the starter phase and in the total period. In addition, there was a trend of better $\mathrm{N}$ retention with the supplementation. Higher $\mathrm{N}$ retention was also observed by Mroz et al. (2000), working with growing pigs supplemented with a complex of formic, fumaric, and butyric acids. The beneficial effect of organic acids and mannanoligosaccharides may be attributed to changes in the intestinal microflora, with modifications associated with the immune response (DAVIS et al., 2004; NOCHTA et al., 2009) and improvement 
in the small intestine morphology (SAVAGE et al., 1996). In the current experiment, the additive effect was more pronounced in the starter phase, which is consistent with the higher digestibility values observed at this stage, due to a maturation improvement in the gastrointestinal tract of the piglet. In addition, the trend of higher $\mathrm{N}$ retention is in accordance with the better growth rate observed at this stage. These results agree with those observed by Poeikhampha and Bunchasak (2011), which showed that dietary supplementation with mannanoligosaccharide and organic acid salts (gluconate and diformate) reduced ammonia production in the large intestine, indicating that less $\mathrm{N}$ was available for fermentation. Devi et al. (2016) also observed improvement in DM, GE, and $\mathrm{N}$ digestibility with diets supplemented only with benzoic acid and not with an additive mix, similarly to the present trial. Blank et al. (1999), by including fumaric acid in weaned piglets' diets, observed an improvement in GE and CP digestibility and in most amino acids. Diao et al. (2016), Halas et al. (2010), and Kluge et al. (2006) also observed positive results in the nutrient digestibility of diets with organic acid supplementation.

In the present experiment, although the $\mathrm{N}$ digestibility increased with the use of additives, no increase in CP was observed. These results are not well elucidated but agree with those found by Omogbenigun et al. (2003) and disagree with those found by Suiryanrayna and Ramana (2015). According to Diao et al. (2016), the improvement in nutrient and energy digestibility is due to the acids' function in reducing the buffering diets' capacity, activating digestive enzymes, reducing nutrient competition with microorganisms adhered to intestinal mucosa, improving mucosal morphology with villi enlargement and crypt reduction, and improving digestibility, absorption, and nutrient retention. The jejunum is the key segment for digestion, nutrient absorption, and transport, as the function of digestion and transport is dependent on intestinal villi. Therefore, an adequate mucosal structure is essential for the improvement of these functions and, consequently, an increase in growth rate. Halas et al. (2010) supplemented the diet with $5000 \mathrm{mg} \mathrm{kg}^{-1}$ of benzoic acid and observed higher villus height and crypt depth, as observed in the Diao et al. (2016) study. Our results do not allow us to conclude about any effect of the additive on the intestinal morphology; however, the improvement in $\mathrm{N}$ digestive capacity could be indicative of a positive effect of the additive on the mucosal structure. However, for other nutrients, no additive effect was observed.

The inconsistent results found in the literature for growth performance and digestibility may be related to the presence or lack of presence of a nutritional challenge, intestinal or sanitary, among studies. Previous research has shown that growth promoters' effect is more pronounced when animals are under some type of challenge (GIANNENAS et al., 2016). Faecal score results corroborate the hypothesis that the use of higher soybean meal levels and barley addition in the diet was not effective to generate intestinal challenge. For example, normal-to-soft stools appeared in $89 \%$ of the observations, whereas diarrhoea appeared in only $7.8 \%$. In addition, the score variation was similar among treatments. No animal was removed from the study because of disease, which could reflect a good health condition in the environment and high health status, which does not allow us to conclude on any additive effect in relation to diarrhoea incidence. These results agree with previous studies in which additive supplementation, such as organic acids (BOAS et al., 2016; ZHANG et al., 2016), manan-oligosaccharides (CHE et al., 2012), or a combination of these (CORASSA et al., 2012), did not influence faecal scores in weaned piglets.

In contrast, when evaluating the supplementation of diets with a mixture of $2.0 \mathrm{mg} \mathrm{kg}^{-1}$ of benzoic acid $+100 \mathrm{mg} \mathrm{kg}^{-1}$ of thymol, Diao et al. (2015) observed diarrhoea reduction. Similarly, Silva et al. (2012) and Zhao et al. (2012) supplemented the piglet diet with $0.1 \%$ and $0.2 \%$ mannan- 
oligosaccharide, respectively, and also observed an effect of this additive on diarrhoea reduction. The authors attributed these results to the ability of the organic acids and mannan-oligosaccharide to inhibit E. coli growth in the gastrointestinal tract. In fact, previous research using these additives in pigs' diets has shown that both have an effect on the inhibition of several pathogenic microorganisms that are usually responsible for the diarrhoea observed in the post-weaning phase (CALVEYRA et al., 2012; DEVI et al., 2016; SBARDELLA et al., 2015; TREVISI et al., 2012). However, reduction in the number of pathogenic organisms has not always been observed in diarrhoea reduction, and the results were dependent on the challenge type imposed on the piglets.

According to our results, intestinal challenge from the diet was not sufficiently able to exacerbate the additive effects. In addition, the growth performance and digestibility results, regardless of supplementation or not with additive, were good; little is left to improve due to the additives. However, our study may contribute to the discussion about the use of alternative antimicrobial additives in pig production. Antibiotics have been banned in the European Union since 2006, and their use has been tightening in all pig production systems around the world. Thus, over the past decades, studies on alternative additives have been given more importance. There is still no clear response to the action of organic acids, mannan-oligosaccharides, or their combination on performance in weaned piglets. The discrepancies between our results and those found in the literature are due to factors such as differences in the weaning age, animal health status, presence of health challenge, diet type, dosage of additives, and genetic potential of the animals.

\section{Conclusions}

We conclude that, in the experimental conditions under which it was tested, the inclusion of an additive with $50 \%$ acetic, propionic, and formic acid and
$50 \%$ mannan-oligosaccharide in diets for weaned piglets does not improve digestibility and does not influence diarrhoea incidence. However, the weight gain and $\mathrm{N}$ balance results were positively influenced by the addition of additive, especially in the starter phase.

\section{References}

ADEOLA, O. Digestion and balance techniques in pigs. In: LEWIS, A. J.; SOUTHERN, L. L. (Ed.). Swine nutrition. Boca Raton: Second Edition, 2001. p. 903-916.

ADEWOLE, D. I.; KIM, I. H.; NYACHOTI, C. M. Gut health of pigs: challenge models and response criteria with a critical analysis of the effectiveness of selected feed additives - a review. Asian Australasian Journal of Animal Science, Seoul, v. 29, n. 7, p. 909-924, 2016. Available at: <https://www.ncbi.nlm.nih.gov/pmc/ articles/PMC4932585/>. Accessed at: 10 sept. 2016.

ASSOCIATION OF AFFICIAL ANALYTICAL CHEMISTS - AOAC. Official methods of the association of official analytical chemists. Arlington: AOAC, 1995. $95 \mathrm{p}$.

BLANK, R.; MOSENTHIN, R.; SAUER, W. C.; HUANG. S. Effect of fumaric acid and dietary buffering capacity on ileal and fecal amino acid digestibilities in early-weaned piglets. Journal of Animal Science, Champaign, v. 77, n. 11, p. 2974-2984, 1999. Available at: $\quad<$ https://www.animalsciencepublications.org/ publications/jas/abstracts/77/11/2974? search-result=1>. Accessed at: 23 nov. 2016.

BOAS, A. D. C. V.; BUDIÑO, F. E. L.; TRINDADE NETO, M. A.; SCHMIDT, A.; DADALT, J. C.; MONFERDINI, R. P.; SITANAKA, N. Y.; MORAES, J. E.; PIZZOLANTE, C. C. Organic acids in diets of weaned piglets: performance, digestibility and economical viability. Arquivo Brasileiro de Medicina Veterinária e Zootecnia, Belo Horizonte, v. 68, n. 4, p. 10151022, 2016. Available at: <http://www.scielo.br/scielo. php?pid=S0102-09352016000401015\&script $=$ sci arttext $>$. Accessed at: 14 feb. 2017.

BROOKS, P. H.; MORAN, C. A.; BEAL, J. D.; DEMECKOVA, V.; CAMPBELL, A. Liquid feeding for the young piglet. In: VARLEY, M. A.; WISEMAN, J. (Ed.). The weaner pig: nutrition and management. Oxon: Varley M. A. and Wiseman J., Editors, 2001. p. 153-178.

BUSSER, E. V.; DEWULF, J.; ZUTTER, L.; HAESEBROUCK, F.; CALLENS, J.; MEYNS, T.; MAES, W.; MAES, D. Effect of administration of 
organic acids in drinking water on faecal shedding of $E$. coli, performance parameters and health in nursery pigs. The Veterinary Journal, London, v. 188, n. 2, p. 184188, 2011. Available at: <http:/www.sciencedirect.com/ science/article/pii/S1090023310001140>. Accessed at: 20 nov. 2016.

CAlveYRA, J. C.; NOGUEIRA, M. G.; KICH, J. D.; BIESUS, L. L.; VIZZOTTO, R.; BERNO, L.; COLDEBELLA, A.; LOPES, L.; MORÉS, N.; LIMA, G. J. M. M.; CARDOSO, M. Effect of organic acids and mannanoligosaccharide on excretion of Salmonella typhimurium in experimentally infected growing pigs. Research in Veterinary Science, London, v. 93, n. 1, p. 46-47, 2012. Available at: <http://www.sciencedirect. com/science/article/pii/S0034528811003572>. Accessed at: 3 nov. 2016.

CHE, T. M.; ADEOLA, O.; AZAIN, M. J.; CARTER, S. D.; CROMWELL, G. L.; HILL, G. M.; MAHAN, D. C.; Miller, P. S.; PETTIGREW, J. E. Effect of dietary acids on growth performance of nursery pigs: a cooperative study. Journal of Animal Science, Champaign, v. 90, n. 12, p. 4408-4413, 2012. Available at: $\quad<$ https://www.animalsciencepublications.org/ publications/jas/articles/90/12/4408?highlight=\&searchresult $=1>$. Accessed at: 21 nov. 2016.

CORASSA, A.; LOPES, D. C.; BELlaVER, C. Mananoligossacarídeos, ácidos orgânicos e probióticos para leitões de 21 a 49 dias de idade. Archivos de Zootecnia, Cordoba, v. 235, n. 61, p. 467-476, 2012. Available at: <http://repositoriodigital.academica.mx/ jspui/handle/987654321/289014>. Accessed at: 5 jan. 2016.

DAVIS, M. E.; BROWN, D. C.; MAXWELL, C. V.; JOHNSON, Z. B.; KEGLEY, E. B.; DROVAK, R. A. Effect of phosphorylated mannans and pharmacological additions of zinc oxide on growth and immunocompetence of weanling pigs. Journal of Animal Science, Champaign, v. 82, n. 2, p. 581-587, 2004. Available at: <https:// www.animalsciencepublications.org/publications/jas/ articles/82/2/0820581>. Accessed at: 19 out. 2016.

DEVI, S. M.; LEE, W. Y.; KIM, I. H. Analysis of the effect of dietary protected organic acid blend on lactating sows and their piglets. Revista Brasileira de Zootecnia, Viçosa, MG, v. 45, n. 2, p. 39-47, 2016. Available at: $\quad<$ http://www.scielo.br/scielo.php?pid=S151635982016000200039\&script $=$ sci arttext $>$. Accessed at: 25 nov. 2016.

DIAO, H.; GAO, Z.; YU, B.; ZHENG, P.; HE, J.; YU, J.; HUANG, Z.; CHEN, D.; DIAO, X. M. Effects of benzoic acid (VevoVitall ${ }^{\circledR}$ ) on the performance and jejunal digestive physiology in young pigs. Journal of
Animal Science and Biotechnology, Seoul, v. 32, n. 7, p. 1-7, 2016. Available at: <https://jasbsci.biomedcentral. com/articles/10.1186/s40104-016-0091-y>. Accessed at: 6 jan. 2017.

DIAO, H.; ZHENGA, P.; YU, B.; HE, J.; MAO, X.; YU, J.; CHEN, D. Effects of benzoic acid and thymol on growth performance and gut characteristics of weaned piglets. Asian Australasian Journal of Animal Science, Seoul, v. 28, n. 6, p. 827-839, 2015. Available at: $<$ https:// www.ncbi.nlm.nih.gov/pmc/articles/PMC4412979/>. Accessed at: 7 jan. 2017.

FESSELE, C.; LINDHORST, T. K. Effect of aminophenyl and aminothiahexyl $\alpha$-D-Glycosides of the manno, gluco, and galacto-series on type 1 fimbriaemediated adhesion of Escherichia coli. Biology, Basel, v. 2, n. 3, p. 1135-1149, 2013. Available at: <http://www. mdpi.com/2079-7737/2/3/1135/htm $>$. Accessed at: 11 out. 2016.

GIANNENAS, I.; DOUKAS, D.; KARAMOUTSIOS, A.; TZORA, V.; BONOS, E.; SKOUFOS, I.; TSINAS, A.; CHRISTAKI, E.; TONTIS, D.; FLOROUPANER, P. Effects of Enterococcus faecium, mannan oligosaccharide, benzoic acid and their mixture on growth performance, intestinal microbiota, intestinal morphology and blood lymphocyte subpopulations of fattening pigs. Animal Feed Science and Technology, Amsterdam, v. 220, p. 159-167, 2016. Available at: $<$ http://www.animalfeedscience.com/article/S03778401(16)30454-0/fulltext>. Accessed at: 28 jan. 2017.

HALAS, D.; HANSEN, C. F.; HAMPSON, D. J.; MULLAN, B. P.; KIM, J. C.; WILSON, R. H.; PLUSKE, J. R. Dietary supplementation with benzoic acid improves apparent ileal digestibility of total nitrogen and increases villous height and caecal microbial diversity in weaner pigs. Animal Feed Science and Technology, Amsterdam, v. 160, p. 137-147, 2010. Available at: $<$ http://www.animalfeedscience.com/article/S03778401(10)00207-5/fulltext>. Accessed at: 14 nov. 2016.

HALAS, V.; NOCHTA, I. Mannan oligosaccharides in nursery pig nutrition and their potential mode of action. Animals, Basel, v. 2, n. 2, p. 261-274, 2012. Available at: $<$ http://www.mdpi.com/2076-2615/2/2/261>. Accessed at: 7 dec. 2016.

KLUGE, H.; BROZ, J.; EDER, K. Effect of benzoic acid on growth performance, nutrient digestibility, nitrogen balance, gastrointestinal microflora and parameters of microbial metabolism in piglets. Journal of Animal Physiology and Animal Nutrition, Berlin, v. 9, n. 7-8, p. 316-324, 2006. Available at: <http://onlinelibrary. wiley.com/doi/10.1111/j.1439-0396.2005.00604.x/full>. Accessed at: 11 nov. 2016. 
KUANG, Y.; WANG, Y.; ZHANG, Y.; SONG, Y.; ZHANG, X.; LIN, Y.; CHE, L.; XU, S.; WU, S.; XUE, B.; FANG, Z. Effects of dietary combinations of organic acids and medium chain fatty acids as a replacement of zinc oxide on growth, digestibility and immunity of weaned piglets. Animal Feed Science and Technology, Amsterdam, v. 208, p. 145-157, 2015. Available at: $<$ http://www.sciencedirect.com/science/article/pii/ S0377840115002382>. Accessed at: 9 dez. 2016.

MARINHO, M. C.; LORDELO, M. M.; CUNHA, L. F.; FREIRE, J. P. B. Microbial activity in the gut of piglets: I. Effect of prebiotic and probiotic supplementation. Livestock Science, Amsterdam, v. 108, n. 3, p. 236-239, 2007. Available at: <http://www.livestockscience.com/ article/S1871-1413(07)00083-2/fulltext>. Accessed at: 23 nov. 2016.

MROZ, Z.; JONGBLOED, A. W.; PARTANEN, K.; VREMAN, P.; KEMME, A.; KOGUT, J. The effects of calcium benzoate in diets with or without organic acids on dietary buffering capacity, apparent digestibility, retention of nutrients, and manure characteristics in swine. Journal of Animal Science, Champaign, v. 78, n. 10 , p. 2622-2632, 2000. Available at: <https://www. animalsciencepublications.org/publications/jas/abstracts /78/10/2622>. Accessed at: 7 feb. 2017.

NOCHTA, I.; TUBOLY, T.; HALAS, V.; BABINSZKY, L. Effect of different levels of mannan-oligosaccharide supplementation on some immunological variables in weaned piglets. Journal of Animal Physiology and Animal Nutrition, Berlin, v. 93, n. 4, p. 496-504, 2009. Available at: <http://onlinelibrary.wiley.com/doi/10.1111/j.14390396.2008.00835.x/full>. Accessed at: 8 jan. 2017.

OMOGBENIGUN, F. O.; NYACHOTI, C. M.; SLOMINSKI, B. A. The effect of supplementing microbial phytase and organic acids to a corn-soybean based diet fed to early-weaned piglets. Journal of Animal Science, Champaign, v. 81, n. 7, p. 1806-1813, 2003. Available at: <http://onlinelibrary.wiley.com/ doi/10.1111/j.1439-0396.2008.00835.x/full>. Accessed at: 23 sep. 2016.

POEIKHAMPHA, T.; BUNCHASAK, C. Comparative effects of sodium gluconate, mannan oligosaccharide and potassium diformate on growth performances and small intestinal morphology of nursery pigs. Asian Australasian Journal of Animal Science, Seoul, v. 24, n. 6, p. 844850, 2011. Available at: <http://www.koreascience. or.kr/article/ArticleFullRecord.jsp?cn=E1DMBP_2011_ v24n6_844>. Accessed at: 21 sep. 2016.

PRATES, E. R. Técnicas de pesquisa em nutrição animal. Porto Alegre: UFRGS, 2007. 414 p.

ROSTAGNO, H. S.; ALBINO, L. F. T.; DONZELE, J. L.;
GOMES, P. G.; OLIVEIRA, R. F.; LOPES, D. C.; FERREIRA, A. S.; BARRETO, S. L. T.; EUCLIDES, R. F. Tabelas brasileiras para aves e suínos: composição de alimentos e exigências nutricionais. Viçosa, MG: Universidade Federal de Viçosa, 2005. 186 p.

SANTOS, V. M.; THOMAZ, M. C.; PASCOAL, L. A. F.; RUIZ, U. S.; WATANABE, P. H.; HUAYNATE, R. A. R.; SILVA, S. Z.; FARIA, H. G. Digestibilidade, desempenho e características morfofisiológicas do trato digestório de leitões desmamados sob dietas com mananoligossacarídeo. Pesquisa Agropecuária Brasileira, Brasília, v. 45, n. 1, p. 99-105, 2010. Available at: <https://seer.sct.embrapa.br/index.php/pab/ article/ view/2857>. Accessed at: 27 nov. 2016.

SAVAGE, T. F.; COTTER, P. F.; ZAKRZEWSKA, E. I. The effect of feeding mannan oligosaccharide on immunoglobulins, plasma IgG and bile IgA of Wrolstad MW male turkeys. Poultry Science, Champaign, v. 75, p. 143, 1996. Supplement 1.

SBARDELlA, M.; PERINA, D. P.; ANDRADE, C.; LONGO, F. A.; MIYADA, V. S. Effects of a dietary added formaldehyde-propionic acid blend on feed enterobacteria counts and on growing pig performance and fecal formaldehyde excretion. Ciência Rural, Santa Maria, v. 45, n. 3, p. 474-479, 2015. Available at: $\quad<$ http://www.scielo.br/scielo.php?pid=S0103$84782014005031660 \&$ script $=$ sci_arttext $>$. Accessed at: 2 dec. 2016.

SILVA, L. P.; NÖRNBERG, J. L. Prebióticos na nutrição de não ruminantes. Ciência Rural, Santa Maria, v. 33, n. 5, p. 983-990, 2003. Available at: $<$ http://revistas.bvsvet.org.br/crural/article/view/15977>. Accessed at: 16 nov. 2016.

SILVA, S. Z.; THOMAZ, M. C.; WATANABE, P. H.; HUAYNATE, R. A. R.; RUIZ, U. S.; PASCOAL, L. A. F.; SANTOS, V. M.; MASSON, G. C. I. H. Mananoligossacarídeo em dietas para leitões desmamados. Brazilian Journal of Veterinary Researcher and Animal, São Paulo, v. 49, n. 2, p. 102-110, 2012. Available at: <http://www.revistas.usp.br/bjvras/article/ view/40265>. Accessed at: 13 dec. 2016.

SUIRYANRAYNA, M. V.; RAMANA, J. V. A review of the effects of dietary organic acids fed to swine. Journal of Animal Science and Biotechnology, Seoul, v. 45, n. 6, p. 1-11, 2015. Available at: <https://dl.sciencesocieties. org/publications/jas/abstracts/81/7/0811806>. Accessed at: 4 jan. 2016.

TREVISI, P.; PRIORI, D.; GANDOLFI, G.; COLOMBO, M.; COLORETTI, F.; GOOSSENS, T.; BOSI, P. In vitro test on the ability of a yeast cell wall based product to inhibit the Escherichia coli $\mathrm{F} 4 \mathrm{ac}$ adhesion 
on the brush border of porcine intestinal villi. Journal of Animal Science, Champaign, v. 90, n. 4, p. 275-277, 2012. Available at: <https://www.animalsciencepublications. org/publications/jas/articles/90/supplement__ 4/275>. Accessed at: 29 sep. 2016.

WALSH, M. C.; ROSTAGNO, M. H.; GARDINER, G. E.; SUTTON, A. L.; RICHERT, B. T.; RADCLIFFE, J. S. Controlling Salmonella infection in weanling pigs through water delivery of direct-fed microbials or organic acids. Part I: Effects on growth performance, microbial populations, and immune status. Journal of Animal Science, Champaign, v. 90, n. 1, p. 261-271, 2012. Available at: <https://www.animalsciencepublications. org/publications/jas/articles/90/8/2599>. Accessed at: 5 nov. 2016.

WALSH, M. C.; SHOLLY, D. M.; HINSON, R. B.; SADDORIS, K. L.; SUTTON, A. C.; RADCLIFF, J. S.; ODGAARD, R.; MURPHY, J.; RICHERT, B. T. Effects of water and diet acidification with and without antibiotics on weanling pig growth and microbial shedding. Journal of Animal Science, Champaign, v. 85, n. 7, p. 1799-1809, 2007. Available at: <https://www. animalsciencepublications.org/publications/jas/articles/ 85/7/0851799>. Accessed at: 9 nov. 2016.
WENNER, B. A.; ZERBY, H. N.; BOLER, D. D.; GEBREYES, W. A.; MOELLER, S. J. Effect of mannan oligosaccharides (Bio-Mos) and outdoor access housing on pig growth, feed efficiency and carcass composition. Journal of Animal Science, Champaign, v. 91, n. 10, p. 4936-4944, 2013. Available at: <https:// www.animalsciencepublications.org/publications/jas/ articles/91/10/4936>. Accessed at: 17 dec. 2016.

ZHANG, Z. F.; ROLANDO, A. V.; KIM, A. V. Effects of benzoic acid, essential oils and Enterococcus faecium SF68 on growth performance, nutrient digestibility, blood profiles, faecal microbiota and faecal noxious gas emission in weanling pigs. Journal of Applied Animal Research, Izatnagar, v. 44, n. 1, p. 173-179, 2016. Available at: <http://www.tandfonline.com/doi/full/10.1 080/09712119.2015.1031765>. Accessed at: 8 feb. 2016.

ZHAO, P. Y.; JUNG, J. H.; KIM, I. H. Effect of mannan oligosaccharides and fructan on growth performance, nutrient digestibility, blood profile, and diarrhea score in weanling pigs. Journal of Animal Science, Champaign, v. 90, n. 3 , p. $833-839,2012$. Available at: <https:// www.animalsciencepublications. org/publications/jas/ articles/90/3/833>. Accessed at: 30 sept. 2016. 
